\title{
Variability and trend analysis of rainfall data of Jhalawar district of Rajasthan, India
}

\author{
Bhim Singh \\ College of Horticulture and Forestry, Jhalarapatan, Jhalawar -326 023 (Rajasthan), INDIA \\ E-mail: bhimsingh1@gmail.com
}

Received: July 31, 2015; Revised received: November 21, 2015; Accepted: January 31, 2016

\begin{abstract}
An attempt has been made to study the variability and trends of annual and seasonal rainfall for the period of 38 years (1973-2010) for all seven tehsils of Jhalawar district of Rajasthan. The mean annual rainfall of the district was found to $910 \mathrm{~mm}$ with standard deviation $218 \mathrm{~mm}$ and coefficient of variation 24 per cent. Annual rainfall varied from about $831 \mathrm{~mm}$ in Khanpur to more than $1022 \mathrm{~mm}$ in the Pirawa tehsil of the district. The annual rainfall showed declined trend $(-0.23$ to $-17.41 \mathrm{~mm} / \mathrm{year})$ in all seven tehsils of the district. The negative trends at Pirawa (17.407 mm/year), Manoharthana (11.595 mm/year) and Aklera (5.789 mm/year) are statistically significant at less than $0.001,0.05$ and 0.05 levels, respectively. During the study period maximum dry period was recorded during postmonsoon and winter. Also, for the entire 38 years period maximum dry months were recorded during December till April. August was normal month for about 87 per cent followed by July and June for about 84 per cent and 66 per cent respectively. It was evident that the onset of south-west (SW) monsoon took place in the month of June and chances of drought occurrence during kharif season were very low. Hence, SW monsoon rainfall is found ideal for raising kharif crops like soybeans, urd, moong, jowar, maize, tomato, brinjal, chilli, okra, kharif onion, amaranth, rainfed green gram, red gram, castor, etc in the district.
\end{abstract}

Keywords: Coefficient of variation, MK-trend test, Precipitation concentration index, Rainfall variability, Sen's slope

\section{INTRODUCTION}

Rainfall is one of the most important natural input resources to the crop production and its occurrence and distribution is erratic, temporal and spatial variations in nature. The knowledge of rainfall in any particular region is very helpful in sound crop planning (Singh and Sharma, 2003). It is natural to imagine that total agricultural production depends, not only on the total rainfall in a season, but also on its pattern of occurrence. The amount and temporal distribution of rainfall are generally the most important determinant of inter-annual fluctuations in national crop production levels. In the extreme case of droughts, with very low total seasonal amounts of rainfall, crop production suffers the most. Many times intra-seasonal variations in rainfall distribution during crop growing periods, without a change in total seasonal amount, can also cause substantial reduction in yield (Bewket, 2009). This means that the number of rainy days during the growing period is as important, if not more, as that of the seasonal total rainfall. The amount and distribution of rainfall in any particular area is very helpful in sound crop planning (Singh and Sharma, 2003) and rainy days were significant and positively correlated with the leafhopper population (Babu and Meghwal, 2014). Many researchers have attempted to study the rainfall analysis for crop plan- ning at different temporal as well as spatial scales (Chand et al., 2011; Jakhar et al., 2011; Jat et al., 2010; Shinde et al., 2010; Subash et al., 2012; Singh et al., 2014). The rainfall distribution in Rajasthan is most uneven and varies considerably from region to region and from year to year. The proper understanding and efficient utilization of the natural resources especially rainfall is therefore, of great concern for the improvement and sustainability of agriculture in rainfed areas. Keeping in view, the present study was conducted to analyze the variability and trends of rainfall data which is expected to be useful for suitable crop planning specific to humid south-eastern region of Rajasthan.

\section{MATERIALS AND METHODS}

Description of the study area: The study was carried out in Jhalawar District of Rajasthan, India. The district falls under Humid South Eastern plain under Zone $\mathrm{V}$ of the Rajasthan state with an area of about $6219 \mathrm{~km}^{2}$ consisting of seven tehsils namely; Khanpur, Jhalarapatan, Aklera, Pachpahar, Pirawa, Manoharthana and Gangdhar (Fig. 1). It resembles English letter ' $S$ ' and lies between $23.45^{\circ}$ and $24.52^{\circ} \mathrm{N}$ and between $75.27^{\circ}$ and $76.56^{\circ}$ E. Jhalawar district has the expansion of fertile plain having rich black-cotton soil and is watered dominantly by $A h u$ 
and Kalisindh rivers. The Arawali hills cross the region roughly dividing the plains of Hadoti from the Malwa plateau. These hills and the surrounding areas provide the district exotic flavour with its diverse range of flora and fauna. Jhalawar district is known for the highest rainfall in Rajasthan. High rainfall along with rich soils provides adequate support to the agriculture in the district.

Climatic characteristics: The long-term mean annual rainfall of the district is $910 \mathrm{~mm}$ with a standard deviation of $218 \mathrm{~mm}$ and a coefficient of variation of $24 \%$. On long term basis, the district experiences 38 mean number of rainy days with a standard deviation of 6 days and a coefficient of variation of $15 \%$. Generally, rainfall in the district is normal and reliable. The annual mean, maximum and minimum monthly relative humidity of the region are $69 \%, 91 \%$ (August) and 40\% (April), respectively. Temperature varies according to altitude. The annual mean, maximum and minimum monthly mean daily temperatures in the district are $27.5^{\circ} \mathrm{C}, 48.8^{\circ} \mathrm{C}$ (May) and 5.5 C (February), respectively.

Data sources and methods of analysis: The rainfall data were collected from District Collectorate, Reve-

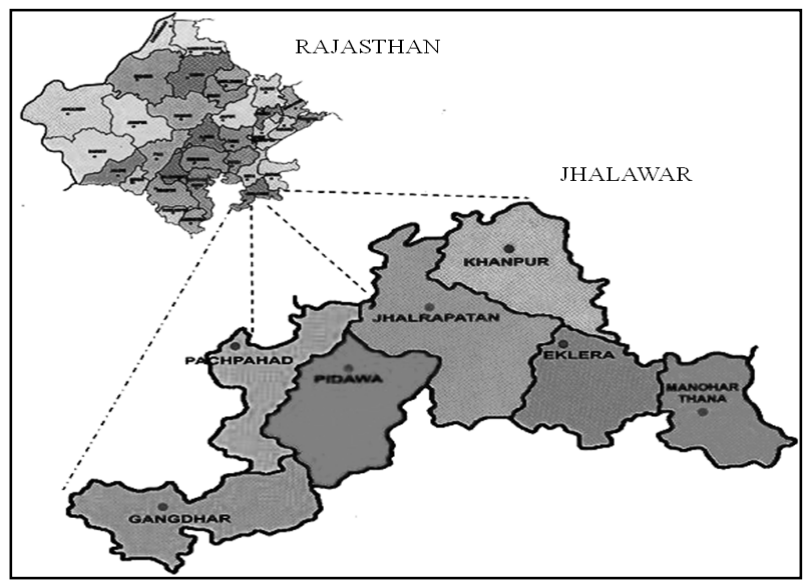

Fig. 1. Jhalawar district and the constituent tehsils.

nue department, Meteorological department, web portal and also from other relevant sources. Data since 1973 up to 2010 of seven tehsils namely; Khanpur, Jhalarapatan, Aklera, Pachpahar, Pirawa, Manoharthana and Gangdhar of the district were collected to draw inferences. Various methods of data analysis were employed in the study. Rainfall data as received from meteorological department were analyzed using

Table 1. Annual and seasonal rainfall (mm), coefficient of variation and PCI during 1973-2010.

\begin{tabular}{|c|c|c|c|c|c|c|c|c|c|c|c|}
\hline \multirow{2}{*}{ Station } & \multicolumn{2}{|l|}{ Annual } & \multicolumn{2}{|c|}{ Pre-monsoon } & \multicolumn{2}{|c|}{ SW monsoon } & \multicolumn{2}{|c|}{ Post- monsoon } & \multicolumn{2}{|c|}{ Winter } & \multirow{2}{*}{$\begin{array}{l}\text { PCI } \\
(\%)\end{array}$} \\
\hline & Mean & $\mathbf{C V}$ & Mean & $\mathrm{CV}$ & Mean & $\mathrm{CV}$ & Mean & $\mathrm{CV}$ & Mean & $\mathrm{CV}$ & \\
\hline Khanpur & 830.7 & 0.22 & 10.1 & 1.41 & 764.1 & 0.25 & 48.8 & 1.32 & 7.6 & 1.33 & 28 \\
\hline Jhalarapatan & 915.8 & 0.34 & 13.7 & 1.13 & 838.8 & 0.35 & 52.2 & 1.40 & 11.1 & 1.77 & 28 \\
\hline Aklera & 894.9 & 0.24 & 14.3 & 1.13 & 824.8 & 0.25 & 45.4 & 1.36 & 10.5 & 1.88 & 26 \\
\hline Pachpahar & 868.1 & 0.29 & 13.1 & 1.38 & 784.6 & 0.30 & 62.8 & 1.23 & 7.6 & 1.57 & 27 \\
\hline Pirawa & 1022.4 & 0.31 & 17.1 & 1.32 & 931.8 & 0.32 & 63.8 & 1.26 & 9.8 & 1.45 & 25 \\
\hline Manoharthana & 988.5 & 0.31 & 15.5 & 1.32 & 905.3 & 0.32 & 55.6 & 1.68 & 12.1 & 2.08 & 25 \\
\hline Gangdhar & 852.3 & 0.31 & 10.0 & 1.16 & 786.0 & 0.35 & 47.6 & 1.12 & 8.7 & 1.47 & 26 \\
\hline District (Jhalawar) & 910.4 & 0.29 & 13.4 & 1.26 & 833.6 & 0.31 & 53.7 & 1.34 & 9.6 & 1.65 & 26 \\
\hline
\end{tabular}

Table 2. Trend statistics and Sen's slopes of annual and seasonal rainfall and its significance.

\begin{tabular}{|c|c|c|c|c|c|c|c|c|c|c|}
\hline \multirow[b]{2}{*}{ Tehsil } & \multicolumn{2}{|c|}{ Annual } & \multicolumn{2}{|c|}{ Pre-monsoon } & \multicolumn{2}{|c|}{ SW monsoon } & \multicolumn{2}{|c|}{ Post- monsoon } & \multicolumn{2}{|c|}{ Winter } \\
\hline & $\begin{array}{c}\text { M-K } \\
\text { test }\end{array}$ & $\begin{array}{l}\text { Rainfall } \\
(\mathrm{mm} / \mathrm{yr})\end{array}$ & $\begin{array}{c}\text { M-K } \\
\text { test }\end{array}$ & $\begin{array}{l}\text { Rainfall } \\
(\mathrm{mm} / \mathrm{yr})\end{array}$ & $\begin{array}{c}\text { M-K } \\
\text { test }\end{array}$ & $\begin{array}{l}\text { Rainfall } \\
(\mathrm{mm} / \mathrm{yr})\end{array}$ & M-K test & $\begin{array}{l}\text { Rainfall } \\
(\mathrm{mm} / \mathrm{yr})\end{array}$ & $\begin{array}{c}\text { M-K } \\
\text { test }\end{array}$ & $\begin{array}{l}\text { Rainfall } \\
(\mathrm{mm} / \mathrm{yr})\end{array}$ \\
\hline Khanpur & -0.075 & -0.230 & -0.569 & 0.000 & 0.075 & 0.150 & -1.285 & -0.303 & 0.000 & 0.000 \\
\hline Jhalarapatan & -0.075 & -0.230 & -0.569 & 0.000 & 0.075 & 0.150 & -1.285 & -0.303 & 0.000 & 0.000 \\
\hline Aklera & $-2.213^{*}$ & -5.789 & 0.473 & 0.000 & $-1.748^{+}$ & -4.675 & $-2.111^{*}$ & -0.794 & -0.812 & 0.000 \\
\hline Pachpahar & -1.509 & -6.283 & 0.630 & 0.000 & -1.559 & -6.618 & -1.842 & -1.443 & 0.263 & 0.000 \\
\hline Pirawa & $-3.709^{* * *}$ & -17.407 & 0.652 & 0.000 & $-3.118^{* * *}$ & -15.629 & $-2.713^{* *}$ & -1.955 & -0.138 & 0.000 \\
\hline $\begin{array}{l}\text { Manohar- } \\
\text { thana }\end{array}$ & $-2.225^{*}$ & -11.595 & 1.612 & 0.171 & $-2.125^{*}$ & -10.636 & -1.325 & -0.297 & -0.263 & 0.000 \\
\hline Gangdhar & -1.559 & -5.083 & 0.463 & 0.000 & -1.220 & -5.250 & -1.545 & -0.546 & -0.135 & 0.000 \\
\hline
\end{tabular}

${ }^{+}$Significant at 0.1 level; ${ }^{*}$ Significant at 0.05 level; ${ }^{* *}$ Significant at 0.01 level; ${ }^{* * *}$ Significant at 0.001 level.

Table 3. Seasonal mean rainfall ( $\bar{x}$ ), Standard deviation (S), normal (N), dry (D) and wet (W) in the study period.

\begin{tabular}{lllllllll}
\hline Season & $\bar{X}$ & S & N & PN & W & PW & D & PD \\
\hline Winter & 9.7 & 13.5 & 12 & 32 & 7 & 18 & 19 & 50 \\
Pre-monsoon & 13.4 & 12.4 & 21 & 55 & 4 & 11 & 13 & 34 \\
SW monsoon & 833.6 & 211.1 & 37 & 97 & 0 & 0 & 1 & 3 \\
Post-monsoon & 53.7 & 65.9 & 11 & 29 & 7 & 18 & 20 & 53 \\
PN- per cent normal, PW- per cent wet, PD- per cent dry & & & & & \\
\hline
\end{tabular}


Table 4. Monthly mean rainfall ( $\bar{X}$ ), Standard deviation (S), normal (N), dry (D) and wet (W) in the study period.

\begin{tabular}{lllllllll}
\hline Month & $\bar{X}$ & $\mathbf{S}$ & $\mathbf{N}$ & $\mathbf{P N}$ & $\mathbf{W}$ & $\mathbf{P W}$ & $\mathbf{D}$ & PD \\
\hline JAN & 5.5 & 9.6 & 8 & 21 & 7 & 18 & 23 & 61 \\
FEB & 4.2 & 8.6 & 10 & 26 & 5 & 13 & 23 & 61 \\
MAR & 2.7 & 6.8 & 4 & 11 & 6 & 16 & 28 & 74 \\
APR & 2.7 & 5.3 & 6 & 16 & 6 & 16 & 26 & 68 \\
MAY & 8.0 & 9.1 & 13 & 34 & 7 & 18 & 18 & 47 \\
JUN & 98.2 & 58.5 & 25 & 66 & 1 & 3 & 12 & 32 \\
JUL & 287.8 & 154.9 & 32 & 84 & 2 & 5 & 4 & 11 \\
AUG & 325.8 & 147.6 & 33 & 87 & 0 & 0 & 5 & 13 \\
SEP & 123.6 & 83.5 & 21 & 55 & 5 & 13 & 12 & 32 \\
OCT & 29.5 & 49.9 & 11 & 29 & 5 & 13 & 22 & 58 \\
NOV & 17.5 & 34.5 & 4 & 11 & 7 & 18 & 27 & 71 \\
DEC & 6.7 & 21.0 & 2 & 5 & 4 & 11 & 32 & 84 \\
PN- per cent normal, PW- per cent wet, PD- per cent dry & & & & & \\
\hline
\end{tabular}

Microsoft Office Excel 2003. Analysis of the rainfall data involved characterizing long-term mean values, and calculation of indices of variability and trends at monthly, seasonal and annual time steps. The coefficient of variation and the Precipitation Concentration Index (PCI) were used as statistical descriptors of rainfall variability. The PCI values were calculated as per the method as suggested by Oliver (1980) as under:

$$
P C I=100 *\left(\frac{\sum P_{i}^{2}}{\left(\sum P_{i}\right)^{2}}\right)
$$

Where, $P i$ is the rainfall amount of the $i^{\text {th }}$ month; and $\Sigma=$ summation over the 12 months.

According to Oliver (1980), PCI values of less than 10 indicate uniform monthly distribution of rainfall, between 11 and 20 high concentration, and that of above 21 very high concentration.

The monthly rainfall series of all the tehsils were used to calculate an areal average rainfall for the district as per the formulae proposed by Nicholson (1985):

$$
R_{j}=\frac{1}{I_{j}} \sum X_{i j}
$$

Where, $R j$ is areally integrated rainfall for year $j ; X i j$ is rainfall at station $i$ for year $j$ and $I j$ is the number of stations available for year $j$. Variability and trend in the areal rainfall were also examined using the same methods.

Trend analysis: The magnitude of the trend in the seasonal and annual series was determined using the Sen's estimator (Sen, 1968) and statistical significance of the trend in the time series was analysed using Mann-Kendall (MK) test (Mann, 1945; Kendall, 1975). Sen's slope method is a nonparametric approach frequently used for environmental data analysis because it is robust to missing data and outliers (Gilbert, 1987) and also gives a robust estimation of trend (Yue et al., 2002). Sen's method calculates the slope as a change in measurement in consonance to the change in time. In this method, the slopes $\left(\mathrm{T}_{\mathrm{i}}\right)$ of all data pairs are first calculated by

$$
T_{i}=\frac{x_{j}-x_{k}}{j-k} \quad \text { for } i=1,2, \ldots, N
$$

Where, $\mathrm{x}_{j}$ and $\mathrm{x}_{k}$ are data values at time $j$ and $k(j>$ $k$ ) respectively. The median of these $\mathrm{N}$ values of $\mathrm{Ti}$ is Sen's estimator of slope which is calculated as

$$
\beta= \begin{cases}T_{\frac{N+1}{2}} & N \text { is odd } \\ \frac{1}{2}\left(T_{\frac{N}{2}}+T_{\frac{N+2}{2}}\right) & N \text { is even }\end{cases}
$$

A positive value of $\beta$ indicates an upward (increasing) trend and a negative value indicates a downward (decreasing) trend in the time series.

In the present study, the MK test was also applied. The MK method searches for a trend in a time series without specifying whether the trend is linear or non -linear. MK test checks the null hypothesis of no trend versus the alternative hypothesis of the existence of increasing or decreasing trend.

The statistic (S) is defined as (Salas, 1993)

$$
S=\sum_{i=1}^{N-1} \sum_{i j=i+1}^{N} \operatorname{sgn}\left(x_{j}-x_{i}\right)
$$

Where, $\mathrm{N}$ is number of data points. Assuming $\left(x_{j}-x_{i}\right)=\theta$, the value of $\operatorname{sgn}(\theta)$ is computed as follows:

$$
\operatorname{sgn}(\theta)=\left\{\begin{array}{rlc}
1 & \text { if } & \theta>0 \\
0 & \text { if } & \theta=0 \\
-1 & \text { if } & \theta<0
\end{array}\right.
$$

This statistic represents the number of positive differences minus the number of negative differences for all the differences considered. For large samples ( $>10)$, the test is conducted using a normal distribution (Helsel and Hirsch, 1992) with the mean and the variance as follows:

$$
E[S]=0
$$




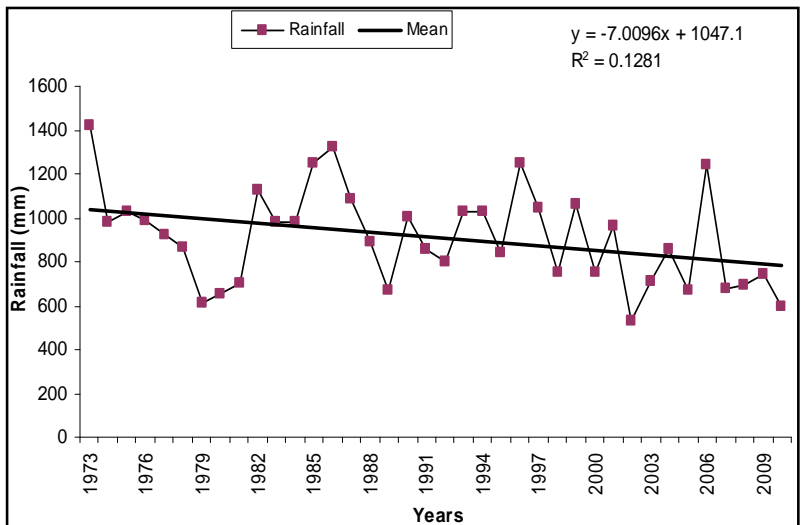

Fig. 2. Annual rainfall trend in Jhalawar.

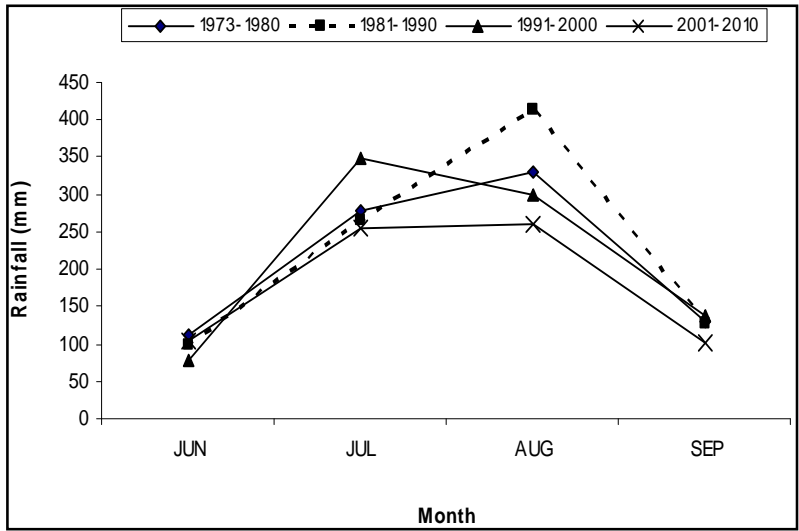

Fig. 3. Trend of south-west monsoon (June-September) rainfall.

$$
\operatorname{Var}(S)=\frac{N(N-1)(2 N+5)-\sum^{n} t_{k}\left(t_{k}-1\right)\left(2 t_{k}+5\right)}{18}
$$

Where, $\mathrm{n}$ is the number of tied (zero difference between compared values) groups, and $t_{k}$ is the number of data points in the kth tied group. The standard normal deviate (Z-statistics) is then computed as (Hirsch et al., 1993):

$$
Z=\left\{\begin{array}{ccc}
\frac{S-1}{\sqrt{\operatorname{Var}(S)}} & \text { if } & S>0 \\
0 & \text { if } & S=0 \\
\frac{S+1}{\sqrt{\operatorname{Var}(S)}} & \text { if } & S<0
\end{array}\right.
$$

If the computed value of $Z>Z_{\alpha / 2}$, the null hypothesis $\left(\mathrm{H}_{0}\right)$ is rejected at $\alpha$ level of significance in a twosided test.

Computation of drought: The criteria used by Sharma et al. (1979) were adopted for computing drought. Any month/season receiving rainfall less than $50 \%$ of the average monthly/seasonal rainfall has been taken as dry month/season (D); between $50 \%$ and $200 \%$ of the average monthly/seasonal rainfall as normal month/season $(\mathrm{N})$ and that receiving rainfall more than twice of average monthly/seasonal rainfall as wet month/season (W).

\section{RESULTS AND DISCUSSION}

The analysis of rainfall data for the period of 38 years

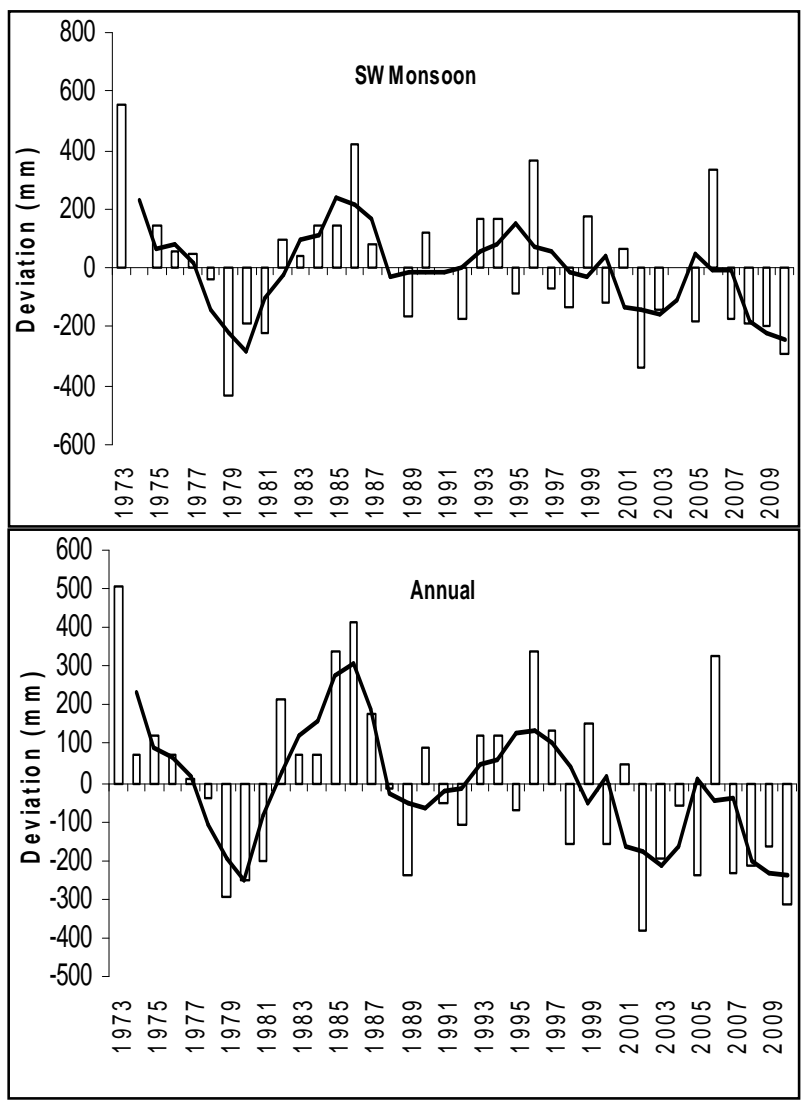

Fig. 4. Deviation of annual and seasonal rainfalls from long term averages (bold line 3-yrs moving average).

(1973 to 2010) indicated that the mean annual rainfall of the district is $910.40 \mathrm{~mm}$ with a standard deviation of $217.67 \mathrm{~mm}$ and a coefficient of variation of 23.90 per cent. The annual total rainfall in the Jhalawar varied from slightly over $831 \mathrm{~mm}$ in Khanpur to more than $1022 \mathrm{~mm}$ in Pirawa tehsil (Table 1). Five tehsils (Khanpur, Gangdhar, Pachpahar, Aklera and Jhalarapatan) received 831 to $916 \mathrm{~mm}$ of mean annual rainfall per year while, two tehsils namely Manoharthana and Pirawa were experienced mean annual rainfall amounts of 989 and $1022 \mathrm{~mm}$, respectively. Thus, Only Pirawa tehsil has experienced more than $1000 \mathrm{~mm}$ of annual rainfall. The rainfall showed moderate inter-annual variability as reflected by the coefficients of variations (Table 1). The winter (January-February), premonsoon (March-May) and post-monsoon (OctoberDecember) rainfalls were found much more variable $(>112 \%)$ than the SW monsoon (main rainy season, June-September) rainfall in which the coefficient of variation is lower than $35 \%$. Much of the rainfall in the study area was found concentrated in the four months of the south-west (SW) monsoon season. The contribution of SW monsoon rainfall to the total annual rainfall was found nearly $92 \%$ in all the tehsils in the district (Table 1). Post-monsoon rainfall had about $5 \%$ to $7 \%$ contribution to the annual total rainfall in all the tehsils. The extreme concentration of rainfall can also be seen from the contribution of the 
single largest monthly total rainfall to annual total rainfall at each of the tehsil. A PCI values noted between 25 and 28 per cent indicate that rainfall in the district was characterized by very high monthly rainfall concentration (Table 1).

Trend analysis of rainfall data indicated a decline trend of annual rainfall during the period under study (Fig. 2). There appeared a declining trend in annual precipitation during the last decade. It gradually declined from $856 \mathrm{~mm}$ (during 2000) to $679 \mathrm{~mm}$ during triennium ending 2010. The annual rainfall shows negative trend in all seven tehsils (Table 2). The statistically significant decreasing trends of annual and SW monsoon rainfall were noted in Pirawa, Manoharthana and Aklera tehsils. The negative trends at Pirawa (17.407 $\mathrm{mm} /$ year), Manoharthana (11.595 mm/year) and Aklera $(5.789 \mathrm{~mm} /$ year $)$ are statistically significant at less than $0.001,0.05$ and 0.05 levels, respectively. Other significant decreasing trends were observed in annual and SW monsoon rainfall of Pirawa and Aklera tehsils (Table 2). However, significant decreasing trend was recorded as concerned of the SW monsoon and annual rainfalls in the district. Similar results of decreasing trends were reported by Roy (2015) in his study for trend detection in temperature and rainfall over Rajasthan during the last century.

Mean and standard deviation of seasonal rainfall for the period of 38 years are presented in Table 3 for drought study. From the data it is evident that SW monsoon season received the highest rainfall $(833.6 \mathrm{~mm})$ followed by the post-monsoon $(53.7 \mathrm{~mm})$, winter $(9.7 \mathrm{~mm})$ and pre-monsoon $(3.4 \mathrm{~mm})$ season. For the entire period, maximum dry season was recorded during postmonsoon and winter. The occurrence of drought during the study period in Post-monsoon and winter seasons were observed as 53 and 50 per cent respectively while during SW monsoon season it was recorded only 3 per cent. It is evident that the onset of rainfall was in the season of SW monsoon and per cent of drought occurrence during SW monsoon (June-September) was negligible. Hence, SW monsoon season is found ideal for raising kharif crops like soybeans, urd, moong, jowar, maize, tomato, brinjal, chilli, okra, kharif onion, amaranth, rainfed green gram, red gram, castor, etc in the district.

From the analysis of monthly rainfall data for the study period it is explicit that August received the highest rainfall followed by July and September (Table 4). December was observed recurrently dry month. Out of 38 December months during the period of study in context, 32 December months were observed dry which constitutes $84 \%$ of total dry month under reference period. During the entire 38 years period under study, maximum dry months were recorded during December till April. April and March received the lowest rainfall (2.7 $\mathrm{mm})$ followed by Feb $(4.2 \mathrm{~mm})$. For the study of the normal rainfall, August was found normal month about $87 \%$ followed by July $(84 \%)$ and June $(66 \%)$. Fig. 3 indicates the decadal amount and pattern of SW monsoon (June-September) rainfall in the district. The average rainfall in the month of August was observed as 413 mm during 1981-1990 while in decade of 20012010, August rainfall was observed as 261. It shows that there was decrease in rainfall peak from 19811990 to $2001-2010$.

The anomalies in the SW monsoon and annual rainfalls are shown in Fig. 4. The rainfall in the district is characterized by alternation of wet years and dry years in a periodic pattern. Of the 38 years of observation, 19 years $(50 \%)$ recorded below the long-term average annual rainfall amount while 19 years recorded above average. Most of the negative anomalies occurred during the 2000s (8 of 19). Between 2002 and 2010 the annual rainfall had been below the longterm mean, excepting the year of 2006 when rainfall was above the mean. During 2002 rainfall amount emerged as the lowest on record in the district, showing the worst drought year. There were seven drought years during the period under study namely 1979, 1980, 1989, 2002, 2005, 2007 and 2010, which together represent $18 \%$ of the total number of observations. In contrast, 1973, 1985, 1986, 1996 and 2006 were wet years and represent $13 \%$ of total observations and the remaining 26 years received normal rainfall which represent $68 \%$ of total observations made during the reported period in the district. The similar types of results were obtained by Rajpoot and Kumar (2014) using 56 year's rainfall data for the assessment of environmental stress as meteorological drought due to rainfall variability in Jaipur, Rajasthan (India).

\section{Conclusion}

An analysis of rainfall variability and trend using the data 1973-2010 showed significant negative trend in the district. The annual total rainfall in the Jhalawar varied from slightly over $831 \mathrm{~mm}$ in Khanpur to more than $1022 \mathrm{~mm}$ in Pirawa tehsil. Five tehsils (Khanpur, Gangdhar, Pachpahar, Aklera and Jhalarapatan) received 831 to $916 \mathrm{~mm}$ of mean annual rainfall per year while, two tehsils namely Manoharthana and Pirawa were experienced mean annual rainfall amounts of 989 and $1022 \mathrm{~mm}$, respectively. Only one tehsil (Pirawa) experienced annual rainfall amounting to more than $1000 \mathrm{~mm}$. The rainfall showed moderate inter-annual variability as reflected by the coefficients of variations. The winter, pre-monsoon and post-monsoon rainfalls were found much more variable $(>112 \%)$ than the $\mathrm{SW}$ monsoon rainfall in which the coefficient of variation is lower than $35 \%$. For the study period, maximum dry period was recorded during post-monsoon and winter with $53 \%$ and $50 \%$ respectively. For the entire 38 years period maximum dry months were recorded during December till April. August was normal month for about $87 \%$ followed by July and June for about 84 and 66 per cent, respectively. It was evident that the onset of SW mon- 
soon took place in the month of June and chances of drought during kharif (June-September) appeared very less under investigation. Recovery of rainfall during the 1990s from the low values of the 1980s obscures decadal scale trends in annual and seasonal rainfall at some tehsils. Many tehsils show drier conditions in 2002 and 2010. Examination of trends in annual and $\mathrm{SW}$ monsoon rainfall in the district is characterized by alternation of wet years and dry years in a periodic pattern.

\section{ACKNOWLEDGEMENTS}

Author express their sincere thank to Meteorological Department, Collectorate Office and Revenue Section, Jhalawar for providing the meteorological data for this study.

\section{REFERENCES}

Bewket, W. (2009). Rainfall variability and crop production in Ethiopia-case study in the Amhara region. In: Proceedings of the 16th International Conference of Ethiopian Studies, ed. by Svein Ege, Harald Aspen, Birhanu Teferra and Shiferaw Bekele, Trondheim 2009, 823836.

Babu, S.R. and Meghwal, M.L. (2014). Population dynamics and monitoring of sucking pests and bollworms on $\mathrm{Bt}$ cotton in humid zone of southern Rajasthan. The Ecoscan, 9(2): 629-632.

Chand, M., Kumar, D., Singh, D., Roy, N. and Singh, D.K. (2011). Analysis of rainfall for crop planning in Jhansi district of Bundelkhand zone of Uttar Pradesh. Indian Journal of Soil Conservation, 39(1): 20-26.

Gilbert, R.O. (1987). Statistical methods for environmental pollution monitoring. John Wiley \& Sons, New York, USA.

Helsel, D.R. and Hirsch, R.M. (1992). Statistical methods in water resources. Elsevier, New York.

Hirsch, R.M., Helsel, D.R., Cohn, T.A. and Gilroy, E.J. (1993). Statistical treatment of hydrologic data. In: Maidment, D.R. (ed.), Handbook of Hydrology, McGraw-Hill, New York, pp. 17.1-17.52.

Jakhar, P., Hombe Gowda, H.C., Naik, B.S. and Barman, D. (2011). Probability analysis of rainfall characteristics of Semiliguda in Koraput, Orissa. Indian Journal of Soil Conservation, 39(1): 9-13.

Jat, M.L., Sammauria, R., Balyan, J.K. and Sharma, R.K. (2010). Crop planning in semi arid tracts of Udaipur region based on analysis of weekly rainfall. Indian
Journal of Soil Conservation, 38(2): 69-74.

Kendall, M.G. (1975). Rank correlation methods. Charles Griffin, London, UK.

Mann, H.B. (1945). Nonparametric tests against trend. Econometrica, 13: 245-259.

Nicholson, S. (1985). Sub-Saharan rainfall 1981-84. Journal of Climate and Applied Meteorology, 24: 1388-1391.

Oliver, J.E. (1980). Monthly precipitation distribution: A comparative index. Professional Geographer, 32: 300309.

Rajpoot, P.S. and Kumar, A. (2014). Assessment of environmental stress as meteorological drought due to rainfall variability in Jaipur, Rajasthan (India). International Journal of Scientific Research in Knowledge, 2(11): 509 $-516$.

Roy, A.D. (2015). Trend detection in temperature and rainfall over Rajasthan during the last century. Asian Journal of Research in Social Sciences and Humanities, 5 (2): $12-26$.

Salas, J.D. (1993). Analysis and modeling of hydrologic time series. In: Maidment, D.R. (ed.), Handbook of Hydrology. McGraw-Hill, New York, 19.1-19.72.

Sen, P.K. (1968). Estimates of the regression coefficient based on Kendall's tau. Journal of American Statistical Association, 63: 1379-1389.

Sharma, H.C., Chauhan, H.S. and Ram, S. (1979). Probability analysis of rainfall for crop planning. Journal of Agricultural Engineering, 16(3): 87-92.

Shinde, S.E., Pathan, T.S., Raut, K.S., More, P.R. and Sonawane, D.L. (2010). Seasonal variations in physicochemical characteristics of Harsool-Savangi dam, district Aurangabad, India. The Ecoscan, 4(1): 37-44.

Singh, B., Arya, C.K., Singh, J. and Mourya, K.K. (2014). Analysis of rainfall data for storage and irrigation planning in humid south-eastern plain of Rajasthan in India. Journal of Applied and Natural Science, 65(2): 245-252

Singh, B. and Sharma, M.K. (2003). A study of pattern of rainfall of crop research station-Masodha (U.P.). Mausam, 54 (2): 552-556.

Subash, N., Singh, S.S. and Priya, N. (2012). Rainfall variability and its impact on change of cropping systems in Bihar. Indian Journal of Soil Conservation, 40(1): 3340.

Yue, S., Pilon, P. and Cavadias, G. (2002). Power of the Mann-Kendall and Spearman's Rho tests for detecting monotonic trends in hydrologic series. Journal of Hydrology, 259: 254-271. 